\title{
The Use of Nuclear Scanning Microprobe to Study Radiation-Induced Migration of Impurities at the Grain Boundaries in Construction Materials
}

\author{
A.V. Romanenko, A.G. Ponomarev \\ Institute of Applied Physics National Academy of Sciences of Ukraine, 58, Petropavlovskaja St., 40000 Sumy, \\ Ukraine
}

(Received 28 November 2015; published online 15 March 2016)

\begin{abstract}
The application of scanning nuclear microprobe for study a radiation-induced migration of impurities at the grain boundaries in structural materials was considered. The work describes the sample preparation for a further irradiation of microscopic areas which include a few grains. Copper samples with deposited sulfur film were used in the present work. Determinations of a chemical composition of the samples, as well as a mapping of the element distribution, were based on the analysis of characteristic paticle induced X-ray emission (PIXE). Two-dimensional distribution maps of elements, that revealed a presence of randomly distributed inclusions of silicon as a result of mechanical treatment, were obtained using the method of micro-PIXE. The quality difference of sulfur films deposited by thermal evaporation and a drop method was shown.
\end{abstract}

Keywords: Nuclear scanning microprobe, Construction material, Impurity, Micro-PIXE method, Sulfur film.

PACS number: 29.30.Ep

\section{INTRODUCTION}

A lot of technological challenges may be faced when new constructional materials for available nuclear reactors and reactors of new generation are created. These challenges are mainly linked to stronger irradiation damages of the materials. Studies of the materials behavior are thus required at thermal and radiation loads. Grain structure is typical for bulk samples. As consequence, impurity segregation at grain boundaries is the primary cause of a material destruction [1-3]. For irradiation effect on segregation to be studied, the following conditions should be fulfilled: 1) beams of high current density for high dose rate are required; 2) different kinds of ions should be used for studying impact of different defects upon a segregation process; 3) mapping of elements distribution is required since segregation occurs at grain boundaries; 4) this method should have low detection limit of atom impurities to detect segregation at early stages. Nuclear scanning microprobe (NSMP) satisfies all the specified conditions. It allows obtaining beams of high current density due to a focusing system. There is also a possibility of obtaining beams of uniform current distribution at a target plane and of preserving size of a focused beam at energy variation without a sample shift [4]. Tandem accelerators that are a basis for nuclear microprobe setup allow obtaining ion beams in a wide range (from hydrogen to bismuth). NSMP permits 2D mapping of element distribution to be obtained using the micro-PIXE technique. It is based on a recording the characteristic Xray radiation at every position of a focused beam in a scanning raster. The technique sensitivity here is two orders of magnitude greater than that of SEM EDS.

Study of impurity diffusion to the grain boundary under radiation is planned in four stages. At the first stage, preparation of the samples of constructional material is required with grain size to study the impurities segregation at their boundaries. At the next stage, a sample surface should be evenly coated with a film of an element that is a specific impurity for the material chosen. The sample is radiated in the area of a film deposition at the third stage. The final stage consists in studying impurity migration at the grain boundaries depending on radiation dose owing to mapping of element distribution.

Application of NSMP in high quality sampling is considered in this work. Copper was chosen as a constructional material; sulfur was taken as an impurity here. The choice was conditioned by an extensive use of copper in accelerator, nuclear technique, in semiconductors. Sulfur is one of the main non-metallic impurities advancing degradation of the selected material and resulting to its destruction.

\section{SAMPLE PREPARATION}

Test samples were made of pure copper. Emery papers and polishing pastes were used for sandpapering and polishing. During the mechanical treatment, the surface condition of the sample was controlled with the microscope MBS-10. Microstructure was detected with a reagent based on chloride of copper ( $4 \mathrm{~g})$ and $25 \%$ aqua ammonia $(50 \mathrm{ml})$. Sulfur film was deposited with two methods: thermal evaporation in VUP and a drop method with a sulfur solution in ethanol used. During sulfur deposition using the VUP, the sample was covered with an aluminum foil with a hole of $\sim 300 \times 400 \mu \mathrm{m}$. The film deposition was performed in three stages because of low density of sulfur and its powdered state. In case of a drop method, thickness of the deposited film was defined with a number of drops precipitated upon one another. Every another drop was deposited after the previous one was dried.

\section{STUDY OF SAMPLES}

The samples were studied at NSMP end-station [5] of IAP NASU analytical accelerating facility. The microPIXE technique was applied for mapping of chemical 
elements distribution [6].

During scanning, the transition from point to point was determined with a value of accumulated charge set by a researcher. Protons with energy of 1.2, 1.5, 1.6 MeV were used in the experiment. Size of a beam on a target was within 4-5 $\mu \mathrm{m}$.

Before sulfur film deposition, the prepared copper samples were examined for impurities that may be revealed during physical treatment. Microstructure of one of the samples is depicted in Fig. 1 to estimate grain size of a copper polycrystal. The area in the white square is of special concern. The samples were put into an interaction chamber and irradiated with a proton beam oriented normally at pressure $10^{-4} \mathrm{~Pa}$. The characteristic Xray radiation was recorded with the Amptek Si-PINdetector XR-100CR. Gained integral spectrum showed presence of silicon in the sample (Fig. 2a). It is positioned non-uniformly and presents the chaotically located impurities that are seen in distribution maps of chemical elements (Fig. 2b). The largest impurities are about $30 \mu \mathrm{m}$ in length (Fig. 2c). The scale to the left shows number of generated X-ray quanta at every point for an energy window that corresponds to a peak width of the selected element. Observed impurities are related to a treatment of the sample since the sandpapers are made of silicon carbide. The sample itself contributes to the unwelcome result because copper is a rather soft material and broken crystals of sandpaper cut into the sample easily. Subsequently, treatment quality was improved and new prepared samples contained no silicon residues (Fig. 3a).

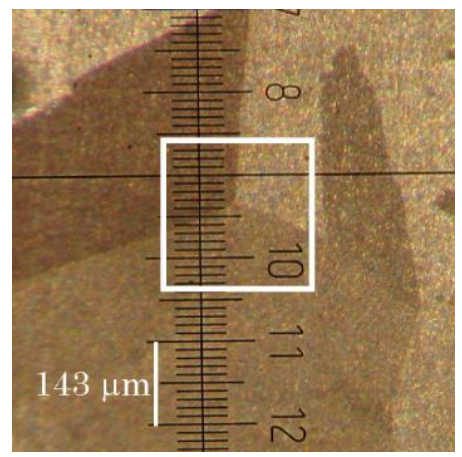

Fig. 1 - Microstructure of a copper sample

Fig. 3b shows a distribution map of elements with size of a sulfur film deposited in VUP. Stand-alone black points on the maps are caused by short-time absence of a bombarding proton beam that resulted in deficiency of generated X-ray quanta. In this case, charge for transition to the next point was gained on account of background current. It happens at data acquisition in a rapid scanning mode when a charge at the point is less than $0.1 \mathrm{nC}$. A detailed examination of the deposited film revealed a non-uniform distribution of sulfur (Fig. 3c).

Size of sulfur film coated with a drop method is $5 \mathrm{~mm}$ in dia. Analysis of the film showed a good uniformity of sulfur distribution (Fig. 4).

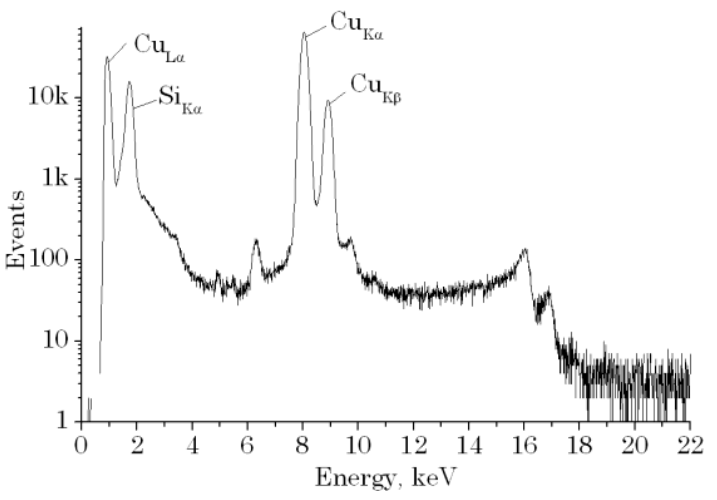

a
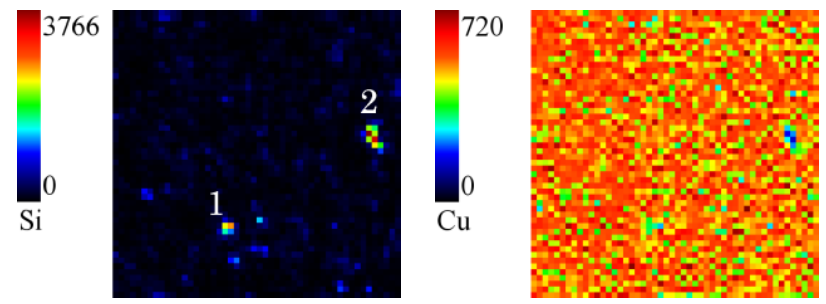

b
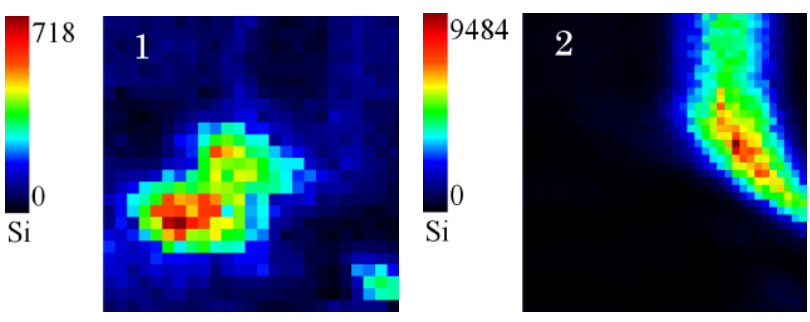

C

Fig. 2 - Analysis of a spectrum area picked in Fig. 1: integral spectrum (a), distribution maps of elements (dot sizes are $250 \times 250 \mu \mathrm{m})$ (b), zoomed impurities (size of a dot 1 is $25 \times 25 \mu \mathrm{m}$, size of a dot 2 is $38 \times 38 \mu \mathrm{m})(\mathrm{c})$

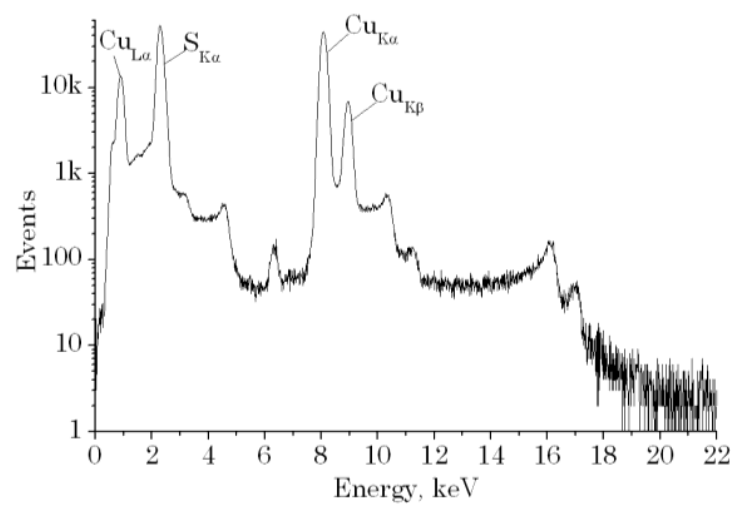

a
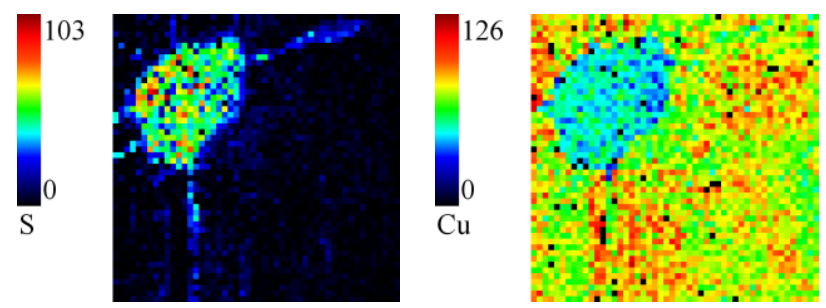

$\mathrm{b}$ 

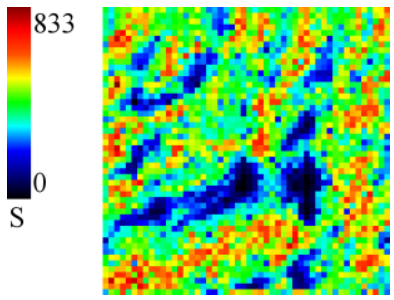

$\mathrm{c}$

Fig. 3 - Distribution of elements in a sample with sulfur film deposited with VUP: integral spectrum (a), general view (size of a dot is $1 \times 1 \mathrm{~mm}$ ) (b), zoomed part of a central film area (size of a dot is $100 \times 100 \mu \mathrm{m})(\mathrm{c})$
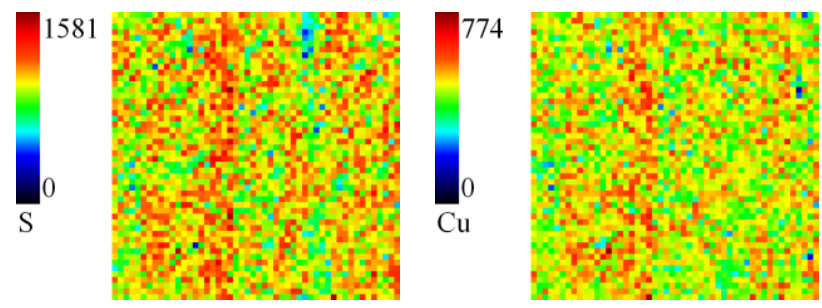

Fig. 4 - Distribution of elements in a sample with sulfur film deposited with a drop method (size of a dot is $200 \times 200 \mu \mathrm{m}$ )

\section{CONSLUSIONS}

The study has proved the efficiency of NSMP that implements a nuclear and physical analytical method to control a sample preparation for the task of radiation-stimulated migration of impurities. After physical and chemical treatment of copper, elements distribution showed that the sample may contain crystals of an abrasive in the form of individual inclusions. The sulfur film deposited with thermal evaporation was shown to have non-uniform distribution related to evaporation peculiarities caused by physical features of the material. The coating obtained with a drop method, instead, is characterized by a good uniformity.

\section{AKNOWLEDGEMENTS}

The work is performed as a part of the project "Precision MeV Beam Formation at Modes of High Density Current and Separate Ions" (State Register No 0111U10610) of the research programme "Development of Advanced Directions of Fundamental Research in Nuclear Radiation Physics and Power Engineering" of Department of Nuclear Physics and Power Engineering NAS of Ukraine.

The authors acknowledge the assistance of Ms. G.A. Torchilo with the preparation of this paper for publication.

\title{
Применение ядерного сканирующего микрозонда для исследования радиационно- стимулированной миграции примесей по границам зерен в конструкционных материалах
}

\author{
А.В. Романенко, А.Г. Пономарев
}

\author{
Институт прикладной фбизики Национальной акаделии наук Украины,, ул. Петропавловская 58, 40000 \\ Сумь, Украина
}

\begin{abstract}
Рассмотрено применение ядерного сканирующего микрозонда в исследованиях радиационностимулированной миграции примесей на границах зерен в конструкционных материалах. Работа посвящена подготовке образцов для проведения облучения микроскопических областей включающих несколько зерен. Образцы представляют собой медь с нанесенной пленкой серы. Определение химического состава образцов, а также построение карт распределения элементов проводилось на основе анализа выхода характеристического рентгеновского излучения (ХРИ) являющегося продуктом взаимодействия облучаемых частиц с атомами мишени. С помощью метода микро-ХРИ получены двумерные карты распределения элементов, которые выявили наличие хаотично расположенных включений кремния возникших в результате механической обработки. Показано различие в качестве пленок серы нанесенных с помощью термо-испарения и капельным методом.
\end{abstract}

Ключевые слова: Ядерный сканирующий микрозонд, Конструкционный материал, Примесь, Метод микро-ХРИ, Пленки серы. 


\title{
Застосування ядерного скануючого мікрозонду для дослідження радіаційно- стимулюючої міграції домішок по границях зерен у конструкційних матеріалах
}

\author{
О.В. Романенко, О.Г. Пономарьов
}

Інститут прикладної фбізики Національної академії наук України, вул. Петропавлівська 58, 40000 Суми, Україна

\begin{abstract}
Розглянуто застосування ядерного скануючого мікрозонду в дослідженнях радіаційностимулюючої міграції домішок на границях зерен у конструкційних матеріалах. Робота присвячена підготовці зразків для проведення опромінення мікроскопічних областей, які включають декілька зерен. Зразки представляють собою мідь з нанесеною плівкою сірки. Встановлення хімічного складу зразків, а також побудова карт розподілення елементів проводилась на основі аналізу виходу характеристичного рентгенівського випромінювання (XРB), яке є продуктом взаємодії опромінюваних частинок із атомами мішені. За допомогою метода мікро-ХРВ отримані двовимірні карти розподілу елементів, які виявили наявність хаотично розташованих включень кремнію, що виникли в результаті механічної обробки. Показано відмінність в якості плівок сірки нанесених за допомогою термо- випаровування і краплинним методом.
\end{abstract}

Ключові слова: Ядерний скануючий мікрозонд, Конструкційний матеріал, Домішка, Метод мікроХРВ, Плівка сірки.

\section{REFERENCES}

1. M. García-Mazarío, A.M. Lancha, M. Hernández-Mayoral, J. Nucl. Mater. 360, 293 (2007).

2. A.M. Ilyin, V.P. Shestakov, I.L. Tazhibaeva, J. Nucl. Mater. 283-287, 161 (2000).

3. R. Völkl, A. Behrends, J. Merker D. Lupton, B. Fischer, Mater. Sci. Eng.: A 368, 109 (2004).

4. A.V. Romanenko, A.G. Ponomarev, J. Nucl. Instr. Meth. B 348,115 (2015).
5. V.E. Storizhko, A.G. Ponomarev, V.A. Rebrov A.I. Chemeris, A.A. Drozdenko, A.B. Dudnik, V.I. Miroshnichenko, N.A. Sayko, P.A. Pavlenko, L.P. Peleshuk, J. Nucl. Instr. Meth. B 260, 49 (2007).

6. M.B.H. Breese, D.N. Jamieson, P.J.C. King, Materials analysis using a nuclear microprobe (New York: John Wiley \& Sons. Ins.: 1996). 